\title{
KETEN TOHUMU YAĞI VE YAĞSIZ SÜT TOZU İÇEREN EMÜLSIYONLARIN PÜSKÜRTEREK KURUTMA İLE ENKAPSÜLASYONU: YAĞ ORANI VE KURUTMA SICAKLIĞININ ETKILERİ
}

\author{
Kutlu ÇEVIK ${ }^{1}{ }^{*}$, Hamza ALAŞALVAR², Mustafa ÇAM ${ }^{3}$, Hasan YALÇIN ${ }^{3}$ \\ ${ }^{1}$ Karamanoğlu Mehmetbey Üniversitesi, Teknik Bilimler Meslek Yüksekokulu, Gıda İșleme Bölümü, Karaman, Niğde Türkiye \\ 2Niğde Ömer Halisdemir Üniversitesi, Mühendislik Fakültesi, Gıda Mühendisliği Bölümü, Niğde, Türkiye \\ 3Erciyes Üniversitesi, Mühendislik Fakültesi, Gıda Mühendisliği Bölümü, Kayseri, Türkiye
}

\begin{tabular}{|c|c|}
\hline Anahtar Kelimeler & $\ddot{\mathbf{O z z}}$ \\
\hline $\begin{array}{l}\text { Keten Tohumu Yağı, } \\
\text { Yağsız Süt Tozu, } \\
\text { Enkapsülasyon Etkinliği, } \\
\text { Püskürtmeli Kurutucu. }\end{array}$ & $\begin{array}{l}\text { Gıda endüstrisinde, yağların oksidatif stabilitesini geliştirmek ve gıda formülasyonlarına } \\
\text { ilavesini kolaylaştırmak için yaygın olarak kullanılan yöntemlerden biri enkapsülasyon } \\
\text { işlemidir. Enkapsülasyon işleminin etkinliği çeşitli faktörlere bağlıdır. Bu çalışmada, keten } \\
\text { tohumu yağının yağsız süt tozu kullanılarak püskürterek kurutma yöntemiyle } \\
\text { enkapsülasyonu amaçlanmıştır. Yağ oranının etkisini belirlemek için üç farklı yağ oranına } \\
(\% 20,40 \text { ve } 60) \text { sahip emülsiyonlar sabit sıcaklıkta }\left(175^{\circ} \mathrm{C}\right) \text { enkapsüle edilmiştir. Sıcaklığın } \\
\text { etkisinin belirlenmesi için de sabit yağ }(\% 40) \text { oranına sahip emülsiyonlar, üç farklı sıcaklıkta } \\
\left(150,175 \text { ve } 200^{\circ} \mathrm{C}\right) \text { enkapsüle edilmiştir. Yüksek sıcaklıklarda }\left(175,200^{\circ} \mathrm{C}\right) \text { yapılan kurutma } \\
\text { işlemlerinde benzer enkapsülasyon verimleri }(\% 39,13-40,74) \text { elde edilmiştir. Ayrıca, en } \\
\text { yüksek enkapsülasyon etkinliği (\%76,63) ise, düşük yağ oranına (\%20) sahip kapsülde } \\
\text { olduğu belirlenmiştir. Yağ oranındaki artışı enkapsülasyon etkinliği üzerine olumsuz etki } \\
\text { göstermiştir (p<0,05). Yağsız süt tozu kullanılarak gerçekleştirilen enkapsülasyon işlemi } \\
\text { sonrasında kapsüllerin akış özellikleri istenilen düzeyde olmamıştır. Ancak yüksek etkinlik } \\
\text { ve verim değerlerinden dolayı keten tohumu yağının enkapsülasyonu için kaplama materyali } \\
\text { olarak yağsız süt tozunun kullanılmasının uygun olduğu görülmektedir. }\end{array}$ \\
\hline
\end{tabular}

\section{ENCAPSULATION OF EMULSIONS CONTAINING FLAXSEED OIL AND SKIM MILK POWDER BY SPRAY DRYING: THE EFFECTS OF OIL RATIO AND DRYING TEMPERATURE}

\begin{tabular}{ll}
\hline Keywords & Abstract \\
\hline Flaxseed Oil, & In the food industry, one of the methods commonly used to improve the oxidative stability of \\
Skim Milk Powder, & oils and to facilitate their addition to food formulations is the encapsulation process. The \\
efficiency of the encapsulation process depends on several factors. In this study, it was aimed \\
to encapsulate flaxseed oil by spray drying using skimmed milk powder. To determine the \\
Spray Dryer. & $\begin{array}{l}\text { effect of oil ratio, emulsions with three different oil ratios }(20,40,60 \%) \text { were spray-dried at } \\
\text { a constant temperature }\left(175^{\circ} \mathrm{C}\right) \text {. Also, an emulsion with a fixed oil ratio }(40 \%) \text { was } \\
\text { encapsulated at three different temperatures }\left(150,175, \text { and } 200^{\circ} \mathrm{C}\right) \text { to evaluate the effect of } \\
\text { temperature. Similar encapsulation yields }(39.13-40.74 \%) \text { were obtained in drying processes } \\
\text { applied at high temperatures }\left(175,200^{\circ} \mathrm{C}\right) . \text { Besides, the highest encapsulation efficiency } \\
\text { (76.63\%) was determined in the capsule having low oil ratio }(20 \%) \text {. The increase in the oil } \\
\text { ratio showed a negative effect on the encapsulation efficiency (p<0.05). The flow properties } \\
\text { of the capsules were an undesirable level after the encapsulation process using skimmed milk } \\
\text { powder. However, it seems suitable to use skimmed milk powder as a coating material for the } \\
\text { encapsulation of flaxseed oil due to its high efficiency and yield values. }\end{array}$ \\
\hline
\end{tabular}

Alıntı / Cite

Çevik, K., Alaşalvar, H., Çam, M., Yalçın, H., (2021). Keten Tohumu Yağı ve Yağsız Süt Tozu İçeren Emülsiyonların Püskürterek Kurutma ile Enkapsülasyonu: Yağ Oranı ve Kurutma Sıcaklığının Etkileri, Mühendislik Bilimleri ve Tasarım Dergisi, 9(3), 735-742.

Yazar Kimliği / Author ID (ORCID Number)

K. Çevik 0000-0003-1187-0901

H. Alaşalvar 0000-0003-3000-7310

M. Çam 0000-0003-1258-0834

H. Yalçın 0000-0002-1038-1877

\begin{tabular}{|l|l|}
\hline Makale Süreci / Article Process \\
\hline Başvuru Tarihi / Submission Date & 24.11 .2020 \\
Revizyon Tarihi / Revision Date & 23.01 .2021 \\
Kabul Tarihi / Accepted Date & 31.01 .2021 \\
Yayım Tarihi / Published Date & 21.09 .2021 \\
\hline
\end{tabular}

* İlgili yazar / Corresponding author: kutlucevik@kmu.edu.tr, +90-338-226-2000 


\section{Giriș (Introduction)}

Keten tohumu (Linum usitatissimum) yağı ticari değere sahip önemli bir bitkisel yağdır. Keten tohumu yağı yüksek oranda (\%75) doymamıș yağ asidi içermekte ve yağ asitlerinin önemli bir kısmını (\%50-60) $\alpha$-linolenik asit (ALA, C18:3) oluşturmaktadır. ALA açısından zengin olan yağlar üzerine son zamanlarda yoğun bir ilgi vardır. Çünkü, ALA hem omega-3 yağ asidi grubuna girmekte hem de insan vücudunda sentezlenemediği için esansiyel yağ asidi olarak kabul edilmektedir (Goyal vd., 2014; Jaček vd., 2020). Omega-3 yağ asitlerinin günlük diyetlerle alınması ile kanser ve kardiyovasküler rahatsızlıkların görülme riski azalmaktadır. Omega-3 yağ asidi tüketimi kandaki toplam kolesterol, LDL (kötü kolesterol), trigliserid seviyesini azalttığı, HDL (iyi kolesterol) seviyesini de arttırdığı bilinmektedir (Figueiredo vd., 2017; Gogus ve Smith, 2010; Stupin vd., 2019). İnsan sağllğı üzerine olumlu etkilerine rağmen, ALA (omega-3) bakımından zengin keten tohumu yağı oksidasyon reaksiyonlarından olumsuz etkilenmektedir. Oksidasyon sonucunda, insan vücudunda toksik etkiler gösterebilecek, tat bozukluklarına ve serbest radikallere neden olan uçucu bileșikler olușmaktadır (Tontul ve Topuz, 2013). Bu sebeple keten tohumu yağı gibi oksidasyon stabilitesi çok düşük olan yağların beslenmede etkin bir şekilde kullanılabilmesi için oksidasyon stabilitesinin arttırılması gerekmektedir.

Enkapsülasyon işlemi, özellikle doymamış yağ asidi oranı yüksek olan yağların oksidasyona stabilitesini ve raf ömrünü arttırmak için uygulanan yaygın bir metottur (Icyer vd., 2017; Linke vd., 2020). Ayrıca bu uygulama ile sıvı formda olan yağ, katı (toz) forma dönüşmekte ve bu sayede kullanım kolaylığı sağlanmaktadır. Enkapsülasyon işleminde uygulanabilirliğinin kolay ve pratik olmasından dolayı püskürterek kurutma metodu gıda endüstrisinde yaygın olarak kullanılmaktadır (Lavanya vd., 2020; Tatar Turan ve Kahyaoglu, 2020). Başarılı bir enkapsülasyon uygulaması için en önemli faktörlerden birisi kaplama materyali seçimidir. Elde edilecek toz ürünlerin enkapsülasyon etkinliği ve enkapsülasyon verimi gibi özellikleri kaplama materyalinin özellikleri ile doğrudan ilişkilidir. Özellikle de yağların enkapsülasyon uygulamalarında kullanılacak olan kaplama materyallerinin emülsifiye edici özelliğinin iyi olması gerekmektedir (Zhang vd., 2020). Kullanılan kaplama materyallerinin fiyatı da gıda endüstrisinde kullanılabilirlik açısından oldukça önemli bir parametredir. Emülsifiye edici özelliklerinden dolayı peynir altı suyu protein konsantresi (WPC), peynir altı suyu protein izolatı, soya proteinleri, jelatin, kazein ve yağsız süt tozu (YST) gibi birçok kaplama materyali yağların enkapsülasyon uygulamalarında kullanılmaktadır (Gharsallaoui vd., 2007). Bu kaplama materyalleri içerisinde ulaşılabilirliğinin kolay olması, fiyatının uygun olması, kurabiye (Chauhan vd., 2015) ve kek (Kaçar ve Sivri Özay, 2019) gibi yaygın tüketimi olan endüstriyel gıda ürünlerinin üretiminde bileşen olarak da kullanılmasından dolayı YST ön plana çıkmaktadır (Shamaei vd., 2017). Balık yağı (Aghbashlo vd., 2013) ve ceviz yağı (Shamaei vd., 2017) gibi doymamış yağ asidi içeriği yüksek olan yağların enkapsülasyonu için YST kaplama materyali olarak kullanılmış ve kaplama materyali olarak etkinliği ortaya konulmuştur. Püskürterek kurutma işleminde, besleme çözeltisi olarak hazırlanan emülsiyonun yağ oranı elde edilen toz ürünlerin fizikokimyasal özellikleri, enkapsülasyon etkinliği ve enkapsülasyon verimi gibi özellikleri üzerine etkilidir. Beslenen emülsiyonun özelliklerinin yanı sıra, püskürtmeli kurutucu işlem şartları da (kurutma sıcaklığı, besleme oranı, hava akış hızı ve aspirasyon hızı) toz ürünlerin özelliklerini etkilemektedir. Bu işlem şartlarından özellikle de kurutma sıcaklığı (giriş sıcaklığı) elde edilen toz ürünlerin özelliklerini doğrudan etkilemektedir (Aghbashlo vd., 2012; Tontul ve Topuz, 2015). Keten tohumu yağı; gam arabik, WPC, modifiye nişasta, maltodekstrin, sodyum kazeinat, laktoz gibi farklı kaplama materyalleri kullanılarak enkapsüle edilmiştir (Goyal vd., 2015; Tonon vd., 2012; Tontul ve Topuz, 2013). Yağların enkapsülasyon uygulamalarında kullanılacak kaplama materyallerinin emülsifiye edici özelliğinin iyi olması gerektiğinden protein ve karbonhidrat içeriği ayarlanarak işlemler gerçekleştirilmektedir. Hem protein (kazein) hem de karbonhidrat (laktoz) içerdiği için YST yağların enkapsülasyon uygulamalarında tek başına kullanılabilmesi mümkündür. YST fiyatının uygun olması, ulaşılabilirliğinin kolay olması gibi olumlu yönlerinden dolayı enkapsülasyon uygulamalarında etkin bir kaplama materyali olarak kullanılabilmektedir (Setyaningsih vd., 2020).

Bu çalışmada, soğuk pres keten tohumu yağının YST kullanılarak püskürtmeli kurutucuyla enkapsüle edilmesi amaçlanmıştır. Püskürtmeli kurutucuya beslenen emülsiyonların yağ oranının ve püskürtmeli kurutucu işlem sıcaklığının toz ürünler üzerine etkileri incelenmiştir. Yağ oranının kapsüller üzerine olan etkisinin belirlenmesi için, farklı yağ oranına sahip emülsiyonlar hazırlanarak sabit şartlarda püskürtmeli kurutucuya beslenerek kapsüller üretilmiştir. Ardından, püskürtmeli kurutucu işlem sıcaklığının etkisini belirlenmesi için, aynı yağ oranına sahip emülsiyonlar hazırlanarak farklı giriş sıcaklıklarında püskürtmeli kurutucu ile kapsüller üretilmiştir. Elde edilen kapsüllerin fizikokimyasal özellikleri incelenmiştir. 


\section{Materyal ve Metot (Material and Method)}

\subsection{Materyal (Material)}

Soğuk pres keten tohumu yağı (Oneva, Türkiye) ve kaplama materyali olarak yağsız süt tozu (YST) (Pınar, Türkiye) yerel marketlerden satın alınmıștır. Çalışmada analitik saflık derecesine sahip kimyasallar (Merck, Almanya) kullanılmiştır.

\subsection{Emülsiyon Hazırlama ve Püskürterek Kurutma (Emulsion Preparation and Spray Drying)}

Püskürtmeli kurutucuya beslenmesi için hazırlanan tüm emülsiyonların kuru madde (yağ+kaplama materyali) oranı \%30 olarak sabit tutulmuştur. İlk olarak, kaplama materyali olan YST saf su içerisine eklenerek manyetik karıștırıcı yardımıyla 10 dakika karıștırılarak homojenize edilmiştir. Sonrasında homojenize edilmiş bu karışıma (saf su+YST) soğuk pres keten tohumu yağı eklenmiş ve homojenizatör (Silverson, L5, İngiltere) yardımıyla maksimum hızda (10.800 rpm) 10 dakika boyunca homojenize edilmiştir. Homojenize edilmiş emülsiyonlar bekletilmeden püskürtmeli kurutucuya beslenmiştir.

Emülsiyonların püskürterek kurutulmasında laboratuvar ölçekli püskürtmeli kurutucu (Buchi B-290, İsviçre) kullanılmıștır. Tablo 1'de belirtilen farklı yağ oranına (\%20, 40 ve 60) sahip örnekler (Y1, Y2 ve Y3) $175^{\circ} \mathrm{C}$ giriş sıcaklığında püskürtmeli kurutucuya beslenerek kapsüller üretilmiştir. Ayrıca, Tablo 1'de belirtilen aynı yă oranına (\%40) sahip örnekler (S1, S2 ve S3) ise 3 farklı sıcaklıkta (150, 175 ve $\left.200^{\circ} \mathrm{C}\right)$ püskürtmeli kurutucuya beslenerek kapsüllerin üretimi gerçekleștirilmiștir. Tüm kurutma işlemlerinde, püskürtmeli kurutucu emülsiyon besleme hızı 8 ml/dk, aspiratör çalıșma hızı \%85 ve hava akıș hızı 600 L/saat olacak șekilde azot gazı kullanılarak kurutma işlemleri yürütülmüştür. Tüm kurutma işlemleri tamamlanana kadar, üretilen kapsüller sızdırmaz cam şişelere aktarılarak $-18^{\circ} \mathrm{C}$ 'de muhafaza edilmiştir.

Tablo 1. Emülsiyonların yağ içeriği ve kurutma işlem sıcaklı̆̆ı değerleri (Oil content and drying process temperature values of emulsions)

\begin{tabular}{|c|c|c|}
\hline Örnek & Yağ oranı (\%) (Kuru maddede) & İșlem sıcaklığı $\left({ }^{\circ} \mathrm{C}\right)$ \\
\hline Y1 & 20 & 175 \\
\hline Y2 & 40 & 175 \\
\hline Y3 & 60 & 175 \\
\hline S1 & 40 & 150 \\
\hline S2 & 40 & 175 \\
\hline S3 & 40 & 200 \\
\hline
\end{tabular}

\subsection{Toz Ürünlerin Analizleri (Analysis of Powder Products)}

\subsubsection{Enkapsülasyon Verimi (EV) (Encapsulation Yield)}

EV değeri, kurutma ișlemi sonrasında toplama haznesinde biriken kapsül miktarı ile püskürtmeli kurutucuya beslenen emülsiyonun kuru madde miktarı arasındaki ilişkiden yararlanılarak Denklem 1'e göre hesaplanmıştır (Kaushik vd., 2016).

$$
E V(\%)=\frac{\text { Kurutma sonrasında üretilen kapsül miktarı }(g)}{\text { Beslenen emülsiyonun kuru madde miktarı }(g)} \times 100
$$

\subsubsection{Enkapsülasyon Etkinliği (EE) (Encapsulation Efficiency)}

Kapsüllerin yüzey yağ değerlerinin belirlenebilmesi için yaklaşık $1 \mathrm{~g}$ kapsül erlen içerisine tartılmış ve üzerine 5 ml petrol eteri eklenerek oda sıcaklığında $5 \mathrm{dk}$ hafifçe karıștırılmıştır. Sonrasında erlende bulunan karışım (kapsül+solvent), sabit tartıma getirilmiş cam kapların (ilk tartım) içerisine Whatman no.1 filtre kâğıdından geçirilerek süzülmüştür. Filtre kâğıdın üzerinde kalan tortu (kapsül) tekrardan 5 ml taze petrol eteri kullanılarak 2 kez yıkanmıştır. Alınan yağ değerinin gravimetrik olarak belirlenebilmesi amacıyla cam kaplar $105^{\circ} \mathrm{C}^{\prime}$ de 1 saat bekletilerek çözücü uzaklaştırılmıştır. Sonrasında cam kap desikatörde soğutularak tartım yapılmış (son tartım) ve Denklem 2'ye göre yüzey yağ değerleri hesaplanmıștır (Bașyiğit vd., 2020). Kullanılan soğuk pres keten tohumu yağı uçucu özellikte olmadığı için beslenen emülsiyonun yağ oranı emülsiyondaki toplam yağ değeri olarak kabul edilmiştir (Tonon vd., 2011). EE değeri ise beslenen emülsiyonun yağ oranı (toplam yağ) ve kapsüllerin yüzey yağ değerleri kullanılarak Denklem 3’e göre hesaplanmıştır (Frascareli vd., 2012).

$$
\text { Yüzey yağ }(\%)=\frac{\text { Son tartım-ìlk tartım }}{\text { Örnek miktarl }} \times 100
$$




$$
E E(\%)=\frac{\text { Toplam yă̆ }- \text { Yüzey yă }}{\text { Toplam Yă }} \times 100
$$

\subsubsection{Su Aktivitesi (Water Activity)}

Kapsüllerin su aktivitesi değeri otomatik su aktivitesi cihazı (AquaLab, ABD) kullanılarak $25^{\circ} \mathrm{C}^{\prime}$ de belirlenmiştir. Yaklaşık 5 g kapsül cihazın haznesine konularak cihazın sabit değere gelmesi beklenmiş ve okunan veriler kaydedilmiştir.

\subsubsection{Nem Analizi (Moisture Analysis)}

Kapsüllerin nem değeri hesaplanabilmesi için cam petri kapları (ilk tartım) sabit tartıma getirilmiştir. Sabit tartıma getirilmiş cam petri kaplarına belirli bir miktarda kapsül tartılmıș ve $105^{\circ} \mathrm{C}^{\prime}$ de $8-10$ saat etüvde (GEMO GT104, Türkiye) bekletilerek yapısında bulunan suyun uzaklaşması sağlanmıştır. Etüvden alınan petri kaplarının soğuması ve ortamdan nem kapmaması için silikajel içeren desikatörde soğumaya bırakılmıştır. Soğuyan petri kapları hassas terazi yardımıyla tartılarak (son tartım) Denklem 4'e göre nem değerleri hesaplanmıştır (AOAC, 2000).

$$
\text { Nem değeri }(\%)=\frac{\text { Son tartım-ìlk tartım }}{\text { Örnek miktarı }} \times 100
$$

\subsubsection{Renk Değeri Analizi (Colour Value Analysis)}

Kapsüllerin renk değerleri ( $L^{*}$; koyu-parlak, $a^{*}$; yeșillik-kırmızllık ve $b^{*}$; mavilik-sarılık) renk tayini cihazı (Konica Minolta CR-5, Japonya) kullanılarak belirlenmiștir. Ayrıca kapsüllerin toplam renk farkı değeri ( $\Delta \mathrm{E}$ ) YST'nin renk

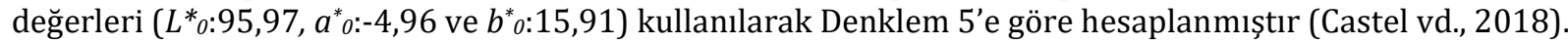

$$
\Delta E=\sqrt{\left(L^{*}-L_{0}^{*}\right)^{2}+\left(a^{*}-a_{0}^{*}\right)^{2}+\left(b^{*}-b^{*}{ }_{0}\right)^{2}}
$$

\subsubsection{Yığın Yoğunluk, Sıkıştırılmış Yoğunluk, Carr İndeks ve Hausner Oranı (Bulk Density, Tapped Density, Carr Index and Hausner Ratio)}

Kapsüllerin yığın yoğunluk değerlerinin belirlenebilmesi için $10 \mathrm{ml}$ hacme sahip cam mezür içerisine herhangi bir baskı uygulamadan toz üründen aktarılmıştır. Yığın yoğunluk değeri, kapsülün kütlesinin kapladığı hacme oranlanmasıyla belirlenmiştir. Sıkıştırılmış yoğunluk ise kapsülün bulunduğu cam mezürün sert bir zemin üzerine saniyede 1 vuruş olacak şekilde $180 \mathrm{kez}$ vurulmasıyla analiz edilmiştir. Sıkıştırılmış yoğunluk değeri, kapsülün kütlesinin vurma ișlemi sonrasında okunan hacme oranlanmasıyla hesaplanmıștır (Tatar ve Kahyaoglu, 2015). Carr indeks ve Hausner oranı değerleri yığın yoğunluk ve sıkıştırılmış yoğunluk değerleri kullanılarak Denklem 6 ve Denklem 7’ye göre belirlenmiștir (Goyal vd., 2015). Hesaplanan veriler kapsüllerin akış özellikleri hakkında bilgi vermektedir.

$$
\begin{aligned}
& \text { Carr index }=\frac{\text { Slkıştırılmış yoğunluk }-Y \text { lğın yoğunluk }}{\text { Sıkıştırılmış ylğın yoğunluk }} \\
& \text { Hausner oranı }=\frac{\text { Slkıștırılmış yoğunluk }}{Y \text { lğ } ı \text { yoğunluk }}
\end{aligned}
$$

\section{4. İstatiksel Analiz (Statistical Analysis)}

Elde edilen sonuçların istatiksel açıdan değerlendirilmesi SPSS 22.0 (SPSS Chicago, ABD) paket programı kullanılarak gerçekleştirilmiştir. Tek yönlü varyans analizi ve Duncan çoklu karşılaştırma testi ile \%95 güven aralı̆̆ında veriler değerlendirilmiştir $(\mathrm{p}<0,05)$.

\section{Bulgular ve Tartışma (Results and Discussion)}

\subsection{Enkapsülasyon Verimi (EV), Yüzey Yağ ve Enkapsülasyon Etkinliği (EE) (Encapsulation Yield, Surface Oil and Encapsulation Efficiency)}

Tablo 1'de belirtilen şartlarda üretilen toz ürünlerin EV değerleri \%27,14-40,74, yüzey yağ değerleri \%4,81-33,02, EE değerleri ise \%44,59-76,63 arasında değişmiştir (Tablo 2 ve Tablo 3). Kurutma sıcaklığının ve emülsiyon yağ oranının değişmesi kapsüllerin EV ve EE değerlerini önemli düzeyde $(p<0,05)$ etkilemiştir. Besleme sonrasında 
elde edilen kapsül miktarı hakkında bilgi veren EV değeri, emülsiyonun yağ oranının artmasından olumsuz yönde etkilenmiștir $(\mathrm{p}<0,05)$. Aynı yağ oranına sahip farklı kurutma sıcaklıklarında üretilen kapsüllerin (S1, S2 ve S3) EV değerleri ise sıcaklık artışından olumlu şekilde etkilenmiştir $(\mathrm{p}<0,05)$. En düşük EV değeri $(\% 27,14), 150^{\circ} \mathrm{C}^{\prime} \mathrm{de}$ kurutma işlemi yapılarak elde edilen S1 numaralı örnekte belirlenmiştir. Düşük sıcaklıklarda yapılan kurutma işleminden üretilen kapsül miktarı düşük olmuştur. Bu durum kurutma işlem sıcaklığının düşük olması sonucu yapıdan suyun uzaklaşmadığı ve kurutma haznesinin iç yüzeyinde daha çok yapışma olması ve dolayısıyla da daha fazla kayıp meydana gelmesi ile açıklanabilir. Yağların enkapsülasyonunda, kurutma sıcaklığının yüksek olması buharlaşmanın daha kısa sürede gerçekleşmesine sebep olmaktadır. Bunun sonucu olarak EV değerinin arttırdığı bilinmektedir (Roccia vd., 2014). Kalkan vd. (2017) tarafından yapılan bir çalışmada, $140-220^{\circ} \mathrm{C}$ sıcaklık aralığında fındık yağı ile hazırladıkları emülsiyonları püskürterek kurutma yöntemi ile enkapsüle etmişlerdir. Elde edilen kapsüllerin EV değerlerinin \%16,37-30,03 arasında değiştiğini ve işlem sıcaklığının artmasının EV değeri üzerine olumlu etki gösterdiğini bildirmişlerdir. Bu durum sıcaklığın artmasıyla kapsüllerin nem değerlerinin düşmesine ve dolayısıyla yapışkanlığın azalmasına atfedilmiştir. Kaushik vd. (2016) tarafından keten tohumu yağını püskürtmeli kurutucu ile enkapsüle edildiği bir çalışmada, kapsüllerin EV değerlerinin \%35,46-52,60 arasında değiştiği rapor edilmiştir.

Farklı kurutma sıcaklıklarında elde edilmiş örneklerin (S1, S2 ve S3) yüzey yağ ve EE değerlerinde önemli bir fark gözlenmemiștir $(p>0,05)$. Yüzey yağ değerlerinin kurutma sıcaklı̆̆ından etkilenmediği belirlenmiștir. Yüzey yağ değeri genelde kaplama materyali ile yağ oranından etkilendiği bilinmektedir (Tonon vd., 2012). Farklı yağ oranına sahip emülsiyonlardan elde edilen kapsüllerin (Y1, Y2 ve Y3) yağ oranının artmasına bağlı olarak yüzey yağ değerinin de önemli düzeyde arttığı $(p<0,05)$, EE değerinin ise önemli düzeyde $(p<0,05)$ azaldığı belirlenmiştir. Yüksek yağ oranına sahip emülsiyonlardan elde edilen toz ürünlerin yüzey yağ değerinin yüksek olması toz üründeki yağ damlacıklarının kapsül yüzeyine difüzyon yolunun kısalmasıyla açıllanabilmektedir. Tontul ve Topuz (2014) yaptıkları bir çalışmada, püskürtmeli kurutucuya beslenen emülsiyondaki yüksek yă̆ oranın toz ürünlerin EE değerini olumsuz yönde etkilediğini bildirmişlerdir. Farklı yağ oranına sahip emülsiyonlardan elde edilen kapsüllerin (Y1, Y2 ve Y3) EE değerlerinin yağ oranının artmasından negatif yönde etkilendiği belirlenmiştir $(\mathrm{p}<0,05)$. Kaushik vd. (2016) tarafından gerçekleștirilen bir çalışmada, farklı oranlarda keten tohumu yağına sahip emülsiyonlar hazırlanmış ve püskürtmeli kurutucu ile enkapsülasyon işlemi gerçekleștirilmiştir. Elde edilen kapsüllerin EE değerlerinin \%73,43-87,60 arasında olduğunu ve püskürtmeli kurutucuya beslenen emülsiyonun yağ oranının artmasıyla EE değerinin olumsuz şekilde etkilendiğini bildirmişlerdir.

Tablo 2. Farklı yağ oranına sahip emülsiyonlardan elde edilmiş toz ürünlerin analiz verileri (Analysis values of powders obtained from emulsions with different oil ratio)

\begin{tabular}{|c|c|c|c|c|c|c|c|c|c|c|c|c|c|}
\hline $\begin{array}{c}\text { Örnek } \\
\text { no }\end{array}$ & EV (\%) & $\begin{array}{c}\text { Yüzey } \\
\text { yă̆ } \\
(\%)\end{array}$ & EE (\%) & $a_{w}$ & $\begin{array}{l}\text { Nem } \\
(\%)\end{array}$ & $L^{*}$ & $a^{*}$ & $b^{*}$ & $\Delta E$ & $\begin{array}{c}\text { Yığın } \\
\text { yoğunluk }\end{array}$ & $\begin{array}{l}\text { Sıkıştırılmış } \\
\text { yoğunluk }\end{array}$ & $\begin{array}{c}\text { Carr } \\
\text { indeks }\end{array}$ & $\begin{array}{c}\text { Hausner } \\
\text { oranı }\end{array}$ \\
\hline Y1 & $\begin{array}{c}33,79 \pm \\
0,59 \mathrm{~b}\end{array}$ & $\begin{array}{l}4,81 \pm \\
0,37 \mathrm{a}\end{array}$ & $\begin{array}{c}76,63 \pm \\
0,94 c\end{array}$ & $\begin{array}{c}0,24 \pm \\
0,01^{b}\end{array}$ & $\begin{array}{c}2,54 \pm \\
0,29 b\end{array}$ & $\begin{array}{c}94,82 \pm \\
0,06^{c}\end{array}$ & $\begin{array}{c}-3,02 \pm \\
0,02 \mathrm{c}\end{array}$ & $\begin{array}{c}11,69 \pm \\
0,12^{a}\end{array}$ & $\begin{array}{l}5,04 \pm \\
0,46^{a}\end{array}$ & $\begin{array}{c}0,23 \pm \\
0,00^{a}\end{array}$ & $\begin{array}{c}0,54 \pm \\
0,01^{\mathrm{a}}\end{array}$ & $\begin{array}{c}58,51 \pm \\
0,00^{\mathrm{b}}\end{array}$ & $\begin{array}{l}2,41 \pm \\
0,00^{b}\end{array}$ \\
\hline Y2 & $\begin{array}{c}35,02 \pm \\
0,81^{b}\end{array}$ & $\begin{array}{c}15,37 \pm \\
1,63^{\mathrm{b}}\end{array}$ & $\begin{array}{c}60,14 \pm \\
2,04^{\mathrm{b}}\end{array}$ & $\begin{array}{l}0,23 \pm \\
0,00^{\text {a }}\end{array}$ & $\begin{array}{l}0,61 \pm \\
0,06^{a}\end{array}$ & $\begin{array}{c}92,69 \pm \\
0,49^{b}\end{array}$ & $\begin{array}{c}-4,44 \pm \\
0,11^{b}\end{array}$ & $\begin{array}{c}18,93 \pm \\
0,20^{\mathrm{b}}\end{array}$ & $\begin{array}{r}5,35 \pm \\
1,44^{\mathrm{a}}\end{array}$ & $\begin{array}{r}0,23 \pm \\
0,01^{\text {a }}\end{array}$ & $\begin{array}{l}0,56 \pm \\
0,02^{\mathrm{a}}\end{array}$ & $\begin{array}{c}59,01 \pm \\
2,88^{b}\end{array}$ & $\begin{array}{c}2,45 \pm \\
0,17 \mathrm{~b}\end{array}$ \\
\hline Y3 & $\begin{array}{c}30,83 \pm \\
0,44^{\mathrm{a}}\end{array}$ & $\begin{array}{c}33,02 \pm \\
0,64^{c}\end{array}$ & $\begin{array}{c}44,59 \pm \\
0,53^{\mathrm{a}}\end{array}$ & $\begin{array}{l}0,22 \pm \\
0,00^{\text {a }}\end{array}$ & $\begin{array}{l}0,47 \pm \\
0,04^{\mathrm{a}}\end{array}$ & $\begin{array}{c}89,11 \pm \\
0,08^{a}\end{array}$ & $\begin{array}{c}-6,16 \pm \\
0,02^{a}\end{array}$ & $\begin{array}{c}32,81 \pm \\
0,59^{c}\end{array}$ & $\begin{array}{c}18,78 \pm \\
0,13^{\mathrm{b}}\end{array}$ & $\begin{array}{l}0,36 \pm \\
0,01^{b}\end{array}$ & $\begin{array}{l}0,62 \pm \\
0,02^{b}\end{array}$ & $\begin{array}{c}41,04 \pm \\
2,91^{\mathrm{a}}\end{array}$ & $\begin{array}{l}1,70 \pm \\
0,08^{a}\end{array}$ \\
\hline
\end{tabular}

a,b,c Aynı sütunda bulunan farklı harfler istatiksel açıdan farklı olduğunu belirtir (p<0,05). Y1: \%20 yağ oranı, Y2: \%40 yağ oranı, Y3: \%60 yağ oranı.

Tablo 3. Farklı giriş sıcaklığında kurutularak elde edilmiş toz ürünlerin analiz verileri

(Analysis values of powders obtained by drying at different inlet temperatures)

\begin{tabular}{|c|c|c|c|c|c|c|c|c|c|c|c|c|c|}
\hline $\begin{array}{c}\text { Örnek } \\
\text { no }\end{array}$ & EV (\%) & $\begin{array}{c}\text { Yüzey } \\
\text { yağ }(\%)\end{array}$ & EE (\%) & $a_{w}$ & $\begin{array}{l}\text { Nem } \\
(\%)\end{array}$ & $L^{*}$ & $a^{*}$ & $b^{*}$ & $\Delta E$ & $\begin{array}{c}\text { Yığın } \\
\text { yoğunluk }\end{array}$ & $\begin{array}{l}\text { Sikıştırılmış } \\
\text { yoğunluk }\end{array}$ & $\begin{array}{c}\text { Carr } \\
\text { indeks }\end{array}$ & $\begin{array}{c}\text { Hausner } \\
\text { oranı }\end{array}$ \\
\hline \multirow{2}{*}{ S1 } & $27,14 \pm$ & $15,36 \pm$ & $61,60 \pm$ & $0,29 \pm$ & $1,97 \pm$ & $93,40 \pm$ & $-4,30 \pm$ & $19,27 \pm$ & $4,29 \pm$ & $0,24 \pm$ & $0,56 \pm$ & $57,96 \pm$ & $2,38 \pm$ \\
\hline & $0,47 \mathrm{a}$ & $3,6^{a}$ & $9,00^{a}$ & $0,00^{c}$ & $0,49 \mathrm{~b}$ & $0,36^{a}$ & $0,10^{\text {ab }}$ & $0,31^{\text {ab }}$ & $0,45^{\mathrm{a}}$ & $0,00^{\mathrm{ab}}$ & $0,01^{\mathrm{b}}$ & $0,93^{a}$ & $0,05^{a}$ \\
\hline \multirow{2}{*}{ S2 } & $40,74 \pm$ & $16,51 \pm$ & $58,72 \pm$ & $0,23 \pm$ & $1,04 \pm$ & $93,42 \pm$ & $-4,66 \pm$ & $20,11 \pm$ & $4,93 \pm$ & $0,25 \pm$ & $0,57 \pm$ & $56,28 \pm$ & $2,29 \pm$ \\
\hline & $0,33^{\mathrm{b}}$ & $2,34^{\mathrm{a}}$ & $5,86^{\mathrm{a}}$ & $0,00^{\mathrm{b}}$ & $0,12^{\mathrm{ab}}$ & $0,09^{\mathrm{a}}$ & $0,16^{\mathrm{a}}$ & $0,55^{\mathrm{b}}$ & $0,51^{\text {a }}$ & $0,00^{\mathrm{b}}$ & $0,01^{\mathrm{b}}$ & $0,26^{\mathrm{a}}$ & $0,01^{\mathrm{a}}$ \\
\hline S3 & $39,13 \pm$ & $15,49 \pm$ & $61,27 \pm$ & $0,19 \pm$ & $0,80 \pm$ & $93,41 \pm$ & $-4,24 \pm$ & $18,50 \pm$ & $3,70 \pm$ & $0,22 \pm$ & $0,50 \pm$ & $56,18 \pm$ & $2,28 \pm$ \\
\hline
\end{tabular}

a,b,c Aynı sütunda bulunan farklı harfler istatiksel açıdan farklı olduğunu belirtir $(\mathrm{p}<0,05) . \mathrm{S} 1: 150^{\circ} \mathrm{C}, \mathrm{S} 2: 175^{\circ} \mathrm{C}, \mathrm{S} 3: 200^{\circ} \mathrm{C}$

\subsection{Su Aktivitesi, Nem ve Renk Analizi Sonuçları (Water Activity, Moisture and Colour Analysis Results)}

Elde edilen kapsüllerin su aktivitesi ve nem değerleri sırasıyla 0,19-0,29 ve \%0,47-2,54 arasında olduğu belirlenmiștir (Tablo 2 ve Tablo 3). Kurutma işlem sıcaklığı ve emülsiyon yağ oranındaki değişimler su aktivitesi ve nem değerlerini etkilemiștir $(\mathrm{p}<0,05)$. Beslenen emülsiyonun yağ oranın artması $175^{\circ} \mathrm{C}$ sıcaklıkta yapılan kurutma işlemi sonucunda elde edilen toz ürünlerin (Y1, Y2 ve Y3) nem değerini önemli düzeyde azaltmıştır $(\mathrm{p}<0,05)$. Bu durumun muhtemel nedeni yağ oranının artmasıyla emülsiyonun zayıflaması ve kurutma işlemi esnasında yapıdaki suyun çok daha kolay buharlaşmasından kaynaklandığı düşünülmektedir. Tonon vd. (2012) tarafından yapılan çalışmada keten tohumu yağı, gam arabik ve modifiye nişasta kullanılarak enkapsüle edilmiştir. 
Çalışmada, beslenen emülsiyonun yağ oranının artmasına bağlı olarak kapsüllerin nem değerlerinde azalma olduğunu bildirilmiştir. Bu çalışmada, farklı sıcaklıklarda yapılan kurutma işlemlerinin kapsüllerin (S1, S2 ve S3) nem değerleri üzerine etkili olduğu belirlenmiştir $(\mathrm{p}<0,05)$. Yüksek kurutma sıcaklıklarında elde edilen kapsüllerin nem değerinin beklendiği gibi önemli düzeyde azaldığı görülmektedir. Giriş sıcaklığını artması yapıdaki suyun çok daha kolay buharlașmasına neden olduğu için nem değeri beklendiği gibi azalmıștır. Kapsüllerin nem değeri püskürtmeli kurutucu giriş sıcaklığıyla yakından ilişkilidir (Aghbashlo vd., 2013). Shamaei vd. (2017) ceviz yağı+YST içeren emülsiyonların $180^{\circ} \mathrm{C}$ 'de püskürterek kurutulması ile üretilen kapsüllerin nem değerlerini \%0,99-1,99 arasında belirlemişlerdir. Bu değerler bu çalışmada keten tohumu yağı+YST içeren emülsiyonlar ile elde edilen kapsüllerin nem değerlerine benzerdir.

Keten tohumu yağı kapsüllerinin renk özellikleri ile ilgili değerler Tablo 2 ve Tablo 3'de verilmiştir. Keten tohumu yağı kapsüllerinin $L^{*}, a^{*}, b^{*}$ ve $\Delta \mathrm{E}$ değerlerinin emülsiyonun yağ oranının değişiminden önemli düzeyde $(\mathrm{p}<0,05)$ etkilenmiştir. Özellikle $b^{*}$ değerinin yağ oranın artmasıyla birlikte önemli düzeyde arttığı sarıya daha yakın bir renk aldığı belirlenmiştir. Bu durumun yüzey yağ ile ilişkili olduğu düşünülmektedir. Yüzey yağ değeri yüksek olan Y3 örneğinin $b^{*}$ değerinin de yüksek olduğu, yani keten tohumu yağının renk özelliklerine daha yakın olduğu anlaşılmaktadır. Yağ oranın değişmediği sadece sıcaklığın değiștiği S1, S2 ve S3 numaralı örneklerin toplam renk değiş̧imi değerine bakıldığında önemli bir etkisinin olmadığı görülmektedir ( $p>0,05)$. Yağ oranının değiştiği Y1, Y2 ve Y3 numaralı örneklerde ise toplam renk değișimi değerinin bu değișimden önemli düzeyde etkilendiği belirlenmiştir $(\mathrm{p}<0,05)$.

\subsection{Carr İndeks ve Hausner Oranı Değerleri (Carr Index and Hausner Ratio Values)}

Kapsüllerin yığın yoğunluğu 0,22-0,36 (g/ $\left.\mathrm{cm}^{3}\right)$ değerleri arasında değişmektedir (Tablo 2 ve Tablo 3). Kurutma işlem sıcaklığının değiștiği örneklerde (S1, S2 ve S3) sıcaklığın artmasıyla yı̆̆ın yoğunluk değerinin azaldığı belirlenmiștir. $\mathrm{Bu}$ durum, yüksek kurutma sıcaklığı ile üretilen kapsüllerin boyutunun büyük olması ile açıklanabilir (Tonon vd., 2011). Aghbashlo vd. (2013) balık yağı+YST içeren kapsüllerin yığın yoğunluk değerlerini 0,248-0,279 (g/ $\left.\mathrm{cm}^{3}\right)$ arasında değiştiğini belirlemişlerdir. Aghbashlo vd. (2013) tarafından yapılan çalışmada 140, 160 ve $180^{\circ} \mathrm{C}^{\prime}$ de yapılan kurutma işlemlerinde sıcaklığın artmasının bağıl yoğunluğunun azalmasına neden olduğunu tespit etmişlerdir. Gözlenen bu azalma, yüksek sıcaklıklarda daha büyük kapsüllerin oluşmasıyla açıklanmıştır.

Kapsüllerin Carr indeks ve Hausner oranı verileri tozların akış özellikleri hakkında genel bilgi vermektedir. Kapsüllerin tașınması esnasında kolaylık sağlaması açısından Carr indeks ve Hausner oranı değerlerinin düșük olması istenmektedir (Goyal vd., 2015). Enkapsülasyon işlemlerinde kullanılan kaplama materyalleri kapsüllerin akış özelliklerini önemli ölçüde etkilemektedir. Carr indeks ve Hausner değerleri sıcaklık değişiminden etkilenmezken $(p>0,05)$, emülsiyonun içerdiği yağ oranından önemli derecede etkilenmiştir $(p<0,05)$. Carr indeks değerinin 25'den büyük olması akış özelliklerinin zayıf olduğunu göstermektedir (Goyal vd., 2015). YST kullanılarak üretilen tüm kapsüllerin Carr indeks değeri 40’ın üzerinde olduğu tespit edilmiștir (Tablo 3 ve Tablo 4) ve akış özelliklerinin zayıf olduğu belirlenmiştir. YST'nin akış özellikleri zayıf olduğu için, YST akıș özelliği iyi olan farklı kaplama materyalleri ile kombine edilerek kullanılması elde edilen toz ürünlerin akış özelliklerini geliştirebileceği düşünülmektedir.

\section{Sonuç ve Öneriler (Conclusion and Suggestion)}

Soğuk pres keten tohumu yağının enkapsülasyonunda kaplama materyali olarak YST’nin kullanılabilirliği, farklı yağ oranlarının ve kurutma sıcaklıklarının kapsüller üzerine olan etkileri incelenerek belirlenmiștir. Yüksek sıcaklıklarda yapılan kurutma ișlemlerinin kapsül verimini olumlu şekilde etkilediği belirlenmiştir. Püskürtmeli kurutucu ile yapılacak kurutma işlemlerinde $175-200^{\circ} \mathrm{C}$ giriş sıcaklığının seçilmesinin enkapsülasyon verimi açısından uygun olduğu görülmektedir. Düşük yağ oranına sahip emülsiyonlardan elde edilen kapsüllerin enkapsülasyon etkinliğinin yüksek olduğu belirlenmiştir. Yağ oranının artması kapsül etkinliğini olumsuz yönde etkilemiş olsa da YST’nin bileșen olarak kullanıldığı kek ve kurabiye gibi endüstriyel ürünlerde yapılacak uygulamalar için kullanılabileceği düşünülmektedir.

\section{Çıkar Çatışması (Conflict of Interest)}

Yazarlar tarafından herhangi bir çıkar çatışması beyan edilmemiştir. No conflict of interest was declared by the authors. 


\section{Kaynaklar (References)}

Aghbashlo, M., Mobli, H., Madadlou, A., and Rafiee, S. 2012. The correlation of wall material composition with flow characteristics and encapsulation behavior of fish oil emulsion. Food Research International, 49(1), 379-388.

Aghbashlo, M., Mobli, H., Madadlou, A., and Rafiee, S. 2013. Influence of Wall Material and Inlet Drying Air Temperature on the Microencapsulation of Fish Oil by Spray Drying. Food and Bioprocess Technology, 6(6), 1561-1569.

AOAC. 2000. Official Methods of Analysis. In Association of Official Analytical Chemists, Washington, DC, 17th edn, vol 2, issue no. 41

Başyiğit, B., Sağlam, H., Kandemir, Ş., Karaaslan, A., and Karaaslan, M. 2020. Microencapsulation of sour cherry oil by spray drying: Evaluation of physical morphology, thermal properties, storage stability, and antimicrobial activity. Powder Technology, 364, 654-663.

Castel, V., Rubiolo, A. C., and Carrara, C. R. 2018. Brea gum as wall material in the microencapsulation of corn oil by spray drying: Effect of inulin addition. Food Research International, 103, 76-83.

Chauhan, A., Saxena, D. C., and Singh, S. 2015. Total dietary fibre and antioxidant activity of gluten free cookies made from raw and germinated amaranth (Amaranthus spp.) flour. LWT - Food Science and Technology, 63(2), 939-945.

Figueiredo, P. S., Inada, A. C., Marcelino, G., Cardozo, C. M. L., Freitas, K. de C., Guimarães, R. de C. A., Hiane, P. A. 2017. Fatty acids consumption: The role metabolic aspects involved in obesity and its associated disorders. Nutrients, 9(10), 1-32.

Frascareli, E. C., Silva, V. M., Tonon, R. V., and Hubinger, M. D. 2012. Effect of process conditions on the microencapsulation of coffee oil by spray drying. Food and Bioproducts Processing, 90(3), 413-424.

Gharsallaoui, A., Roudaut, G., Chambin, O., Voilley, A., and Saurel, R. 2007. Applications of spray-drying in microencapsulation of food ingredients: An overview. Food Research International, 40(9), 1107-1121.

Gogus, U., and Smith, C. 2010. n-3 Omega fatty acids: a review of current knowledge. Internaional Journal of Food Science and Technology, 45(3), 417-436.

Goyal, A., Sharma, V., Sihag, M. K., Tomar, S. K., Arora, S., Sabikhi, L., and Singh, A. K. 2015. Development and physicochemical characterization of microencapsulated flaxseed oil powder: A functional ingredient for omega-3 fortification. Powder Technology, 286, 527-537.

Goyal, A., Sharma, V., and Upadhyay, N. 2014. Flax and flaxseed oil : an ancient medicine \& modern functional food. Journal of Food Science and Technology, 51(9), 1633-1653.

Icyer, N. C., Toker, O. S., Karasu, S., Tornuk, F., Kahyaoglu, T., and Arici, M. 2017. Microencapsulation of fig seed oil rich in polyunsaturated fatty acids by spray drying. Journal of Food Measurement and Characterization, 11(1), 50-57.

Jaček, M., Hrnčírová, D., Rambousková, J., Dlouhý, P., and Tůma, P. 2020. Effect of food with low enrichment of N-3 fatty acids in a two-month diet on the fatty acid content in the plasma and erythrocytes and on cardiovascular risk markers in healthy young men. Nutrients, 12(8), 1-12.

Kaçar, D., and Sivri Özay, D. 2019. Olive oil shortenings as an alternative to commercial shortenings in cake production: physical and sensory properties. Journal of Food Measurement and Characterization, 13(4), 2846-2852.

Kalkan, F., Vanga, S. K., Murugesan, R., Orsat, V., and Raghavan, V. 2017. Microencapsulation of hazelnut oil through spray drying. Drying Technology, 35(5), 527-533.

Kaushik, P., Dowling, K., McKnight, S., Barrow, C. J., and Adhikari, B. 2016. Microencapsulation of flaxseed oil in flaxseed protein and flaxseed gum complex coacervates. Food Research International, 86, 1-8.

Lavanya, M. N., Kathiravan, T., Moses, J. A., Anandharamakrishnan, C., Kathiravan, T., Moses, J. A., and Anandharamakrishnan, C. 2020. Influence of spray-drying conditions on microencapsulation of fish oil and chia oil. Drying Technology, 38(3), 279-292.

Linke, A., Hinrichs, J., and Kohlus, R. 2020. Impact of the powder particle size on the oxidative stability of microencapsulated oil. Powder Technology, 364, 115-122.

Roccia, P., Martínez, M. L., Llabot, J. M., and Ribotta, P. D. 2014. Influence of spray-drying operating conditions on sunflower oil powder qualities. Powder Technology, 254, 307-313.

Setyaningsih, D., Kurniawan, D., and Muna, N. 2020. Encapsulation of ginger oleoresin with a combination of maltodextrin and skim milk powder as wall material. IOP Conference Series: Earth and Environmental Science, 472,1-11.

Shamaei, S., Seiiedlou, S. S., Aghbashlo, M., Tsotsas, E., and Kharaghani, A. 2017. Microencapsulation of walnut oil by spray drying: Effects of wall material and drying conditions on physicochemical properties of microcapsules. Innovative Food Science and Emerging Technologies, 39, 101-112.

Stupin, M., Kibel, A., Stupin, A., and Mihalj, M. 2019. The Physiological Effect of n-3 Polyunsaturated Fatty Acids (n3 PUFAs) Intake and Exercise on Hemorheology, Microvascular Function, and Physical Performance in Health and Cardiovascular Diseases; Is There an Interaction of Exercise and Dietary n-3 PUF. Frontiers in Physiology, 10, 1129. 
Tatar, F., and Kahyaoglu, T. 2015. Microencapsulation of Anchovy (Engraulis encrasicolus L.) Oil: Emulsion Characterization and Optimization by Response Surface Methodology. Journal of Food Processing and Preservation, 39(6), 624-633.

Tatar Turan, F., and Kahyaoglu, T. 2020. The effect of an ultrasonic spray nozzle on carbohydrate and proteinbased coating materials for blueberry extract microencapsulation. Journal of the Science of Food and Agriculture, 101(1), 120-30.

Tonon, R. V., Grosso, C. R. F., and Hubinger, M. D. 2011. Influence of emulsion composition and inlet air temperature on the microencapsulation of flaxseed oil by spray drying. Food Research International, 44(1), 282-289.

Tonon, R. V., Pedro, R. B., Grosso, C. R. F., and Hubinger, M. D. 2012. Microencapsulation of Flaxseed Oil by Spray Drying: Effect of Oil Load and Type of Wall Material. Drying Technology, 30(13), 1491-1501.

Tontul, I, and Topuz, A. 2013. Mixture Design Approach in Wall Material Selection and Evaluation of Ultrasonic Emulsification in Flaxseed Oil Microencapsulation. Drying Technology, 31(12), 1362-1373.

Tontul, Ismail, and Topuz, A. 2014. Influence of emulsion composition and ultrasonication time on flaxseed oil powder properties. Powder Technology, 264, 54-60.

Tontul, Ismail, and Topuz, A. 2015. Chapter 13. Microencapsulation of Plant Oils Rich in Alpha-Linolenic Acid_ Effect of Processing Parameters. Microencapsulation and Microspheres for Food Applications, 253-270.

Zhang, Y., Pang, X., Zhang, S., Liu, L., Ma, C., Lu, J., and Lyu, J. 2020. Buttermilk as a wall material for microencapsulation of omega-3 oils by spray drying. LWT - Food Science and Technology, 109320. 